\title{
口腔粘膜病の検討（診断, 治療の立場から）
}

\section{その 2, 類天疱瘡性口内炎の症例}

\author{
松田登・佐々木初太郎
}

\section{（I）緒言}

天疮瘡といら疾患自体は比較的ま机な疾患で，水疮形 成を主症状とする慢性皮膚病性のものである。この病気 は，(1) 口腔に始めに症状が出ること，(2) 経過中口腔 に執ようにく门か光し生ずるので，口腔病変の占める洒 值は大きい、私達はさきに，尋常性天泡瘡の 2 例につい

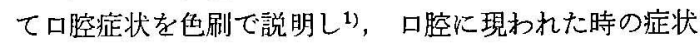
の特徴をよくわきまえて，出来るだけ早く正しい䛦断を

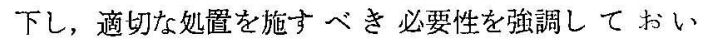
$た^{2 / 3)}$

今回，33才の男子の口腔粘膜に天疮痘とすこぶる類 似したいわゆる類天疱性の症状を現わし，速かに適切な 診断と処置を行ならことにより全治せしめることが出来 た症例を記述する．慢性口内炎として取り扱われている ものの中には，こらいら要因がもつとあつてよいはずで ある.注意して鑑別診断をつけることに役立てばこの報 告の目的は详せられると思う。

\section{(II) 症例}

患者：【 33 才

家族歴：特記すべきことはない，

既往歴: 28 才の時, 肺結核で右肺の部分切除手術を らけた. 経過は良好である。

現病歴：39 年 11 月 $\square$ 日より風邪気味で，口の中 が荒れたよらな感があつた，気になるので 18 日診㙩所 に受診，口内炎と診断され，デカドロンとクロマイの投 与をらけ，多少自覚症状はよくなった，しかし，薬物の 服用にもかかわらず水疮と思われるものが舌，頓粘膜に 多発したので， 39 年 11 月 当科を紹介された。

主訴：接触痛による食餉摄取障害

\section{現症}

全身所見：栄養，体格中等度で，皮䖉や他の粘膜には 病変はない, 体温 $37.2^{\circ} \mathrm{C}$

口腔内所見：頓粘膜全体は浮腫性で白みをおびた数個 の大きな水疮の破れた被膜がみられる(写真 1 矢印)。周 因の発赤は少ない，一部は麻爛となり，斑絞状を呈して いる. 口唇にも類似の症状がある. 舌は浮随性で全体的 に白濁してみ兄る. 表面に $4 \sim 5$ 個の大きな水疮が破れ て生した剥離性の被膜が，べっとりと付着している（写

\footnotetext{
* 群馬大学医学部药科（主任檴師松田登）
}

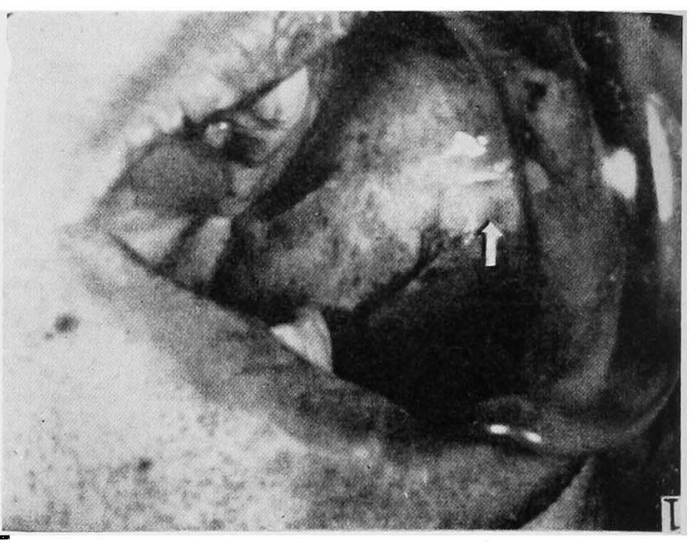

写真 1 矢印，煩粘膜の水疮疮

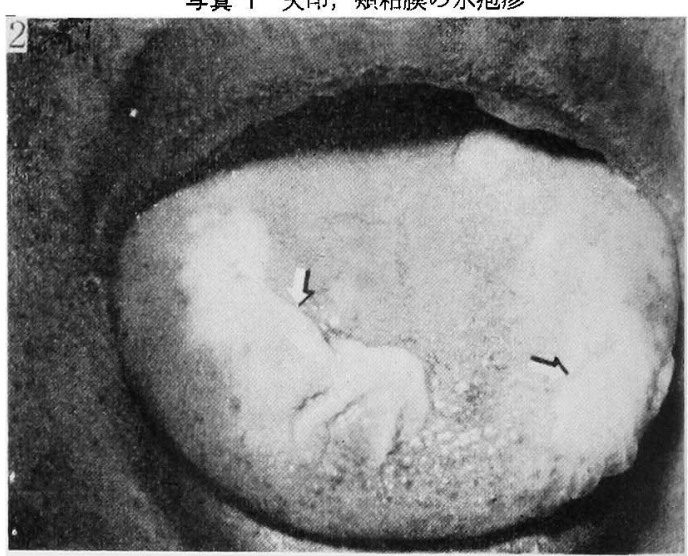

写真 2 矢印舌に生じた水疮疹，周囲の発柇は汪とんどない

真 2 矢印)。こすると制れ，その下から出血し，生々しい

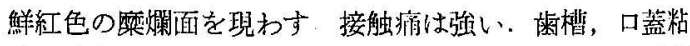
膜の症状は，他の部よりもはるかに毦い，咽頭には病变 はない，四腔内は粘稠で，口臭がある、リンパ腺は O.B.

\section{臨床検 查成樍}

赤血球数 482 万, 白血球数 6800 ,

白血球の種類：中性嫩好分葉核 $57 \%$ ，桿状核 $2 \%$, エオジン搘好 $5 \%$, リンパ球 $33 \%$, 大监核球 $3 \%$. エ オジン愭好, リンパ球の增加が目立つ.

血 沈: 30 分値 $5 \mathrm{~mm}, 60$ 分值 $10 \mathrm{~mm}$ で添ぽ正常. 椎倠血滥反応陰性.

尿所見 : O. B. 


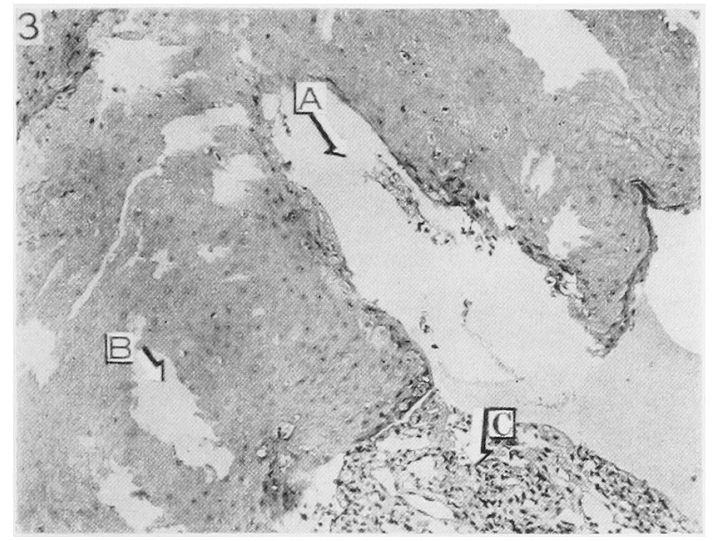

写真 3 矢印 $\mathrm{A}$. 上皮直下の水泡疹

B. 上皮内の小水疱

C. 細胞浸潤

肝機能: BSP. 30 分値 10\%，で軽度の肝障害がみら れる。

細菌検査：塗抹，培養，グラム染色. グラム陽性ブド ウ状球菌を得たが，二次的のものと思う。

病理組織所見：写真 3 は舌で, 上皮の基細胞層の直上 において梀細胞の融触像があり水疱の形成がみられる (A). 上皮層内にも小水疱が多数存在する (B). 粘謨下 組織に，リンパ球，好中球の浸潤がある(C).

診 断 : 水疮形成, エオジン嗜好細胞の增加などの臨 秝上の特長と，組織所見より粘膜天疱㾣とした。

処 置：確実な診断が下されるまで，クロタオン，線 維素分解酵素剂 [バリダーゼ・オーラル］の服朋，ブド ウ糖, 各種ビタミン剤の投与, 局所に無刺激性消毒剂の 塗布を行なつた８日間無効. 診断確定挠，リンデロン [ベタメサゾン］1日3 mg [朝，午後 2 回に分服］を 内服させ，局所にデスパューワを慾布させた。すこぶる 有效で, 新しい水疮の形成はなく，4日後には口腔粘膜 の接触痛は軽減し, 出血は止み, 留燘面には上皮の新生 が文られた７日後. 食慨撕取可能となり，リンデロン $1 \mathrm{mg}$ を維持量として約 1 力月服用せしぬた．ステロイ ド内服による副作用はなく，現在なでの所再発はない ( 2 ケ月)

\section{（III）考案}

\section{1）類天疮犄性口内炎とした理由}

1）薬物性口内炎とは考党られない。これは，バルビ タール，アスピリン，サルファー剤などに対する特異体 質者における口内炎で，薬物使朋有血学問診で知ること が出来るし，普通 1 ～週間後には消失するはずである. クロラムフェーコールでもまれにはおこるが，本症例で はデカドロンと併用してあるので，その可能性は非常に 少ないはずである。

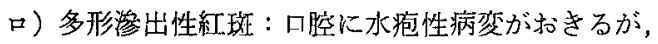

紅斑は著明でもつと赤くただれたよう外倠を呈する。

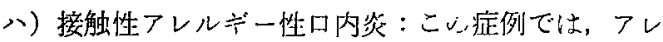
ルギーの因子となる物質はないよらである。

）インフルエンザ，感骨などの熱性疾患に継発して 生ずる水疱性口内炎：登熱を伴い，経週は一過性，抗生 物質の投与で症状は好転するはずである。

ホ）ワンサン氏口内炎，漬凘性口内炎，流行怢口阿炎 [Trench mouthなど：水疮形成は普通ないし，スピ 口ヘータと紡鐘状桿菌が多数発兒され，崡肉の激しい疼

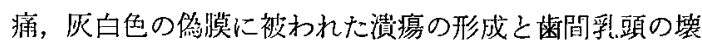
死を生ずる。発熱，出血性，リンパ節の腫脹など症状は 急激で，慢性の経過をとるこのものとはかなりの差があ る.このよらに鑑别してゆくと，水疮形成を主症状とす る本症例は，あまり経過は慢性とはい充ないが，皮䖉症 状が末だ現われていない初期の天疱瘡性口内炎，いわゆ る類天疮瘡性の口内炎としか考えられない，奏際，組繊 像やエオジン㖺㶩細胞の增加という臨床検至成績も出て いるので，ほぼ，上訰の骖断を下しても間違いはないと 思5.

（2）天泡痻性口内炎についての2，3の私達の意見

この病気は最初に口腔に症状を示すことが多く，普通 の口内炎の治療を行なつても一向に治らず，全身に水疱 疹が出来て始めて天疮瘡と診断されることが多い（Ste$\mathrm{rn}$ ). 一般に粘膜に出現する水疮性ないし潰瘍性疾患は， 多様性を示さないので見ただけでは鑑别は䩪つかい。

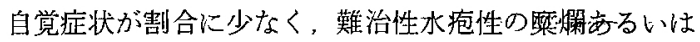

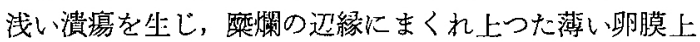
の上皮残をのこしているのならばまず第一に天庖瘡を矤 い，病理組織検查をはじめ充分な臨床検査を行なわねば $+5 \times 2$.

口腔症状は診断上，または予後の判定に重要な意義を 有することはいらまでもない，皮膚症状を示さない初期 のらちに出来るだけ早く発見し，処置したいものである. この意味から本症例ば適切な片針を示す一つの指標にな れば幸いと思う。

從来, 難治珄の疾患の1つとして举げられていたので あるが，最近，副腎皮質ホルモンの適切な使用法により 激烈な症状を和らげ，抺転させたといら報告は多い、私 達は，ベタメサジン[リンデロン] 炎投与して、すみや かに症状を消失させ，もら少し経過をおつて観察する必 要はあると思らが，現在再発をみていない，副腎皮質製 绪は粘膜だけに限局している早期のうちに用いると非常 に役立つものである．局所処置として，デスハコーワ (興和新薬) の塗布は，局所症状の軽減という意味で役 立つから併用守べきである。

\section{（IV）結論}

私達は，1）33才の男性で，天狍㾑性と思はれる病変 
がロ腔内だけに止まっている初期のうらに診断を下し， ベタィサゾンの投与で治療した1例をのべた。

2 ）先に報告した症例の追加の意味之, 口腔診断, 治 療学の立場からみると、このような例はもう少し多いよ らに思われる。こういう観点から本症例をみていただき たいという希望をのべた。

\section{文献}

1）布施貞夫, 松田 登: 口腔病誌, $27: 172$ (昭 35)

2）布施貞夫, 松田 登: 歯界展望, $14: 361$ (昭 32)

3）松田 登, 日本口胫科誌, $4: 78$, (昭 30)

4）布施貞夫他：臨床口腔科学， 2 版，168 頁. 医料蒋出版. (昭 33)

5) P. L McCarthy : Diseases of the Oral mucosa, 1759. McGraw-Hill. 1964.

6) L. W. Burket : Oral Medicine, 3 rd, 1459 Lippincott. 1957 